\title{
ФОРМУВАННЯ ФАХОВОЇ КОМПЕТЕНТНОСТІ МАЙБУТНЬОГО ВИКЛАДАЧА ВОКАЛУ ЗАСОБАМИ МУЛЬТИМЕДІЙНИХ ТЕХНОЛОГІЙ
}

\author{
Мережко Ю. В., Киченко Т. О.
}

\section{ВСТУП}

На сучасному етапі в Україні відбувається становлення нової системи освіти, оріснтованої на вступ у світовий освітній простір. Одним із важливих напрямів розвитку суспільства $є$ його глобальна інформатизація. Комп'ютерні технології дедалі глибше проникають у життя людини, а інформаційна компетентність дедалі більше визначає рівень ії освіченості та фахової компетентності.

Стрімкий технологічний розвиток, інтеграційні соціальноекономічні процеси, формування єдиного інформаційного простору завдяки інтернету зумовили появу низки соціальних проблем. Чинні традиційні системи освіти не повністю задовольняють сучасні суспільні вимоги, недостатньо зорієнтовані на перспективні потреби суспільного життя, що стає перешкодою для належної підготовки особистості до майбутньої фахової діяльності.

Поява пристроїв для запису й обробки звукової інформації, спеціалізованих комп'ютерних програм відкрила нову сторінку в музичному житті суспільства. У XXI ст. вони стали доступними для широкого загалу, а також застосовуються у професійній музичній діяльності. Використання цих досягнень прогресу відкриває великі перспективи в мистецькій освіті, а також створює передумови для модернізації освітньої сфери.

У науковій літературі компетентність у сфері педагогічної діяльності учителя досліджували О. Бігич, Н. Кузьміна, А. Маркова, О. Мармаза, О. Овчарук, Р. Рогожнікова, О. Савченко, В. Стрельніков, А. Хуторська та ін., безпосередньо у фаховій підготовці майбутнього вчителя музики іiі розкрили Е. Абдулін, Л. Арчажнікова, П. Ніколаєнко, О. Олексюк, О. Реброва, В. Шульгіна та ін.

Вивченням i застосуванням комп'ютерних технологій i мультимедійних методик у сфері гуманітарних наук займалися науковці Л. Бородкін, Л. Минович Т. Манфред, А. Бінгхем, П. Меннінг, в освітній галузі - М. Жалдак, В. Ткачук; у мистецтві - I. Гайденко, Б. Голешевич, М. Опалєв, Л. Покровщук， Я. Пруденко, К. Фадєєва, у 
процесі музичного навчання - О. Бондаренко, О. Бордюк, Ю. Дворник, В. Луценко, Н. Новикова, О. Піксаєва, О. Чайковська та ін. Проте проблема формування фахової компетентності майбутнього викладача вокалу засобами мультимедійних технологій висвітлена недостатньо.

Активне впровадження комп'ютерних і мультимедійних технологій у галузь музичного навчання та фахової музичної підготовки вчителів музики викликає інтерес наукової спільноти, а недостатня теоретична i методична розробленість проблеми, потреби практики зумовили вибір теми наукового дослідження: «Формування фахової компетентності майбутнього викладача вокалу засобами мультимедійних технологій».

\section{1. Мультимедійні технології як засіб формування фахової компетентності майбутнього викладача вокалу}

Важливою ознакою сучасного суспільства $\epsilon$ його глобалізація та суцільна інформатизація, яка переформатовує усі світові процеси розвитку, галузі науки, сфери людського буття.

3 появою технологій мультимедіа, пристроїв для запису й обробки звукової інформації, спеціалізованих комп'ютерних програм відкрито нову сторінку в музичному житті суспільства, професійній музичній діяльності, а також у музичній освітянській галузі.

Суттєвою перевагою мультимедійних технологій перед іншими технічними засобами $\epsilon$ імітація реальності, що відбувається в діалоговому режимі. Розвиток діалогових систем мультимедіа призвів до появи підручників, енциклопедій, атласів, журналів та інших навчальних засобів.

Сьогодні «стала аксіомою думка про те, що сучасний викладач вокалу має досконало володіти вміннями аранжування, перекладання, композиції, інструментовки; вмінням працювати 3 комп'ютерним обладнанням, цифровими й аналоговими інструментами та застосовувати їх у професійній діяльності» ${ }^{1}$.

Поширеність мультимедіа як сфери комп'ютерної технології можна пояснити тим, що їх суттєва перевага - поєднання в одному технічному засобі (комп'ютері) функцій інших технічних засобів (наприклад, магнітофону, відеоплеєра і т. п.), результатом чого $є$ можливість працювати із програмами, оснащеними анімацією, стереозвуком, відеозображенням і великою кількістю інших відео- й аудіоефектів ${ }^{2}$.

${ }^{1}$ Іванова С.М. Структурний аналіз комунікативної компетентності майбутнього вчителя музики. Наука і сучасність. 2007. Т. 60. С. 56-64.

${ }^{2}$ Вербицкий А.А. Активное обучение в высшей школе: Контекстный подход. Москва : Высшая школа, 1991. 105 с. 
На підставі аналізу наукових досліджень вважаємо доцільним розглянути більш детально можливості мультимедіа та визначити напрями їх застосування. Мультимедіа використовується як:

- технологія, що описує порядок розробки, функціонування i застосування засобів обробки інформації різних типів;

- інформаційний ресурс, створений на основі технологій обробки та представлення інформації різних типів;

- комп'ютерне програмне забезпечення, функціонування якого пов'язане з обробкою і представленням інформації різних типів;

- комп'ютерне апаратне забезпечення, за допомогою якого стає можливою робота з інформацією різних типів ${ }^{3}$.

За визначенням словника, мультимедіа - інтерактивна технологія, що забезпечує за допомогою технічних і програмних засобів роботу з анімованою комп'ютерною графікою і текстом, мовою, високоякісним звуком, нерухомими зображеннями і рухомим відео ${ }^{4}$.

Водночас у широкому розумінні термін «мультимедіа»- спектр IКТ, які використовують різні програмні та технічні засоби з метою більш ефективного впливу на користувача (котрий є одночасно i читачем, і слухачем, і глядачем).

Ми пропонуємо розмежувати означене поняття на такі складники:

- поєднання (синергію) різних цифрових типів інформації, таких як текст, зображення, звук і відео й утворення із цієї сукупності єдиного (комплексного) мультисенсорного інтерактивного додатку;

- обладнання (засоби), призначені для роботи з різними типами цифрової інформації;

- інтерактивний програмний продукт, що поєднує перераховані вище типи інформації.

Узагальнюючи викладене вище, пропонуємо операційне тлумачення поняття мультимедійні технологї - комплекс програмних та апаратних засобів, які дозволяють користувачу працювати з графікою, текстом, звуком, відео у вигляді єдиного мультисенсорного додатку.

Зроблений аналіз сутності поняття мультимедіа, в основі якого $є$ трискладовість (мультимедіа-ідея, мультимедіа-засоби, мультимедіапродукт), дозволяє окреслити напрями опанування технологій мультимедіа майбутніми фахівцями.

3 Горляков П.Ю. Понятие компетентности и особенности профессиональноориентированного обучения иностранному языку. Общество. URL: http://www.terrahumana.ru /arhiv/10_03/10_03_24.pdf.

4 Коряпина В.В. Педагогический менеджмент как средство оптимизации образовательного процесса в учреждениях среднего профессионального образования. URL: http://dissland.com/. 
Вивчаючи можливості застосування мультимедійних технологій у фаховій підготовці вчителів, О. Лановенко окреслює такі переваги у поданні інформації: збільшення (деталізацію) на екрані зображення або його фрагментів при збереженні якості. Це особливо важливо для презентації творів мистецтва й унікальних історичних документів; виділення окремих областей у текстовому, графічному зображенні, візуалізованому музичному творі, а завдяки технології гіпертексту i гіпермедіа - можливість швидкого отримання довідкової або будь-якої іншої пояснювальної інформації; можливість роботи 3 різними додатками (текстовими, графічними та звуковими редакторами); створення звукового супроводу та його синхронізація зі статичним або динамічним візуальним рядом; використання відеофрагментів із фільмів, відеозаписів і різноманітних функцій управління відтворенням («стоп-кадр», покадрове «гортання» відеозапису та ін.); супровід розповіді демонстрацією баз даних, інфографікою, анімаційною презентацією різноманітних технік i технологій; можливість автоматичного перегляду продукту («слайд-шоу») та використання ігрових компонентів 3 інформаційними складниками; можливість «вільної» навігації та виходу в основне меню (або із програми) в будьякій точці продукту; підключення до глобальної мережі Internet ${ }^{5}$.

Ми погоджуємося $з$ таким переліком, але вважаємо, що в контексті музичної освіти комплекс переваг є значно ширшим.

О. Пиксаєва наводить напрями використання комп'ютерних технологій у музичній освіті для вирішення таких завдань:

- музикознавчих;

- мистецтвознавчих;

- науково-дослідних;

- об'єктивних методів оцінки результатів педагогічної праці у процесі навчання;

- діагностики рівня музичного та вокального розвитку учнів;

- використання як технічних засобів навчання;

- програмованого навчання через створення навчальних програм із різних музичних дисциплін та ін ${ }^{6}$.

Ми погоджуємося 3 поглядами науковців у тому, що комп'ютерні та мультимедійні технології сприяють формуванню певних якостей фахівця: пізнавальної самостійності, творчої активності, творчих якостей.

${ }^{5}$ Иванова А. Психологическая комфортность диалога человека с комп'ютером : автореф. дис. ... канд. псих. наук : 19.00.03. Москва, 1991. С. 18.

6 Жалдак М. Використання комп'ютера в навчальному процесі має бути педагогічно виваженим. Інформатика та інформаційні технологї в навчальних закладах. 2013. № 1. С. 10-18. 
Але вважаємо, що коло їх наукового інтересу більшою мірою стосується вдосконалення певної особистісної характеристики технологіями мультимедіа, і недостатньо уваги приділяється методиці ефективного використання мультимедіа у фаховій діяльності викладача.

Проте існує дещо інше спрямування застосування інформаційнокомунікаційних технологій (ІКТ) у фаховій підготовці.

Так, погляди О. Бордюка більше фокусуються на методичних засадах формування вмінь, знань використання IКТ технологій у фаховій діяльності. Автор розглядає програмне забезпечення мистецького напряму: для забезпечення набору, редагування, виведення на друк нотного тексту, автоматичного аранжування нотних текстів - Finale, Sibelius, Encore, Steinberg Cubase, Jammer Pro, Easy Keys i Band-in-a-Box; для опанування навичками запису та редагування аудіофайлів, аудіоредактори - Sound Forge, Nuendo, Adobe Audition, Cool Edit Pro, Wave-Editors.

Розширення можливостей комп'ютера в освітньому процесі дозволяє передати значну кількість функцій педагога саме йому. Викладач виконує роль керівника-дослідника, котрий спрямовує студента на активізацію навчальної діяльності та створює умови для іiі реалізації. Він також використовує певну методичну схему для організації заняття за певною типологією, наповнюючи його щоразу новим змістом. Звичайно, таке заняття вимагає творчої та професійної гнучкості від викладача. На різних етапах проведення заняття 3 постановки голосу вчитель може скористатися допомогою комп'ютера, використовуючи його як засіб інтенсифікації навчання на етапі пояснення нового матеріалу 3 ілюстрацією найбільш цікавих пізнавальних фрагментів, епізодів; для закріплення набутих знань i вмінь, де комп'ютерна підтримка сприяє продуктивній організації та проведенню заняття тощо.

Слід зазначити, що використання мультимедійних технологій у системі фахової підготовки майбутніх викладачів вокалу, на нашу думку, має дещо інший характер - «потрійності», оскільки технології мультимедіа одночасно є: 1) предметом вивчення; 2) інструментом набуття фахових знань; а також 3) ефективним засобом фахової діяльності. Усі напрями $є$ взаємозалежними. Мультимедіа, безумовно, потенційно розширює обсяг i різноманітність інформації, доступної студентам. Але ми вважаємо, що лише той мультимедійний додаток може мати навчальний, виховний $\mathrm{i}$ розвиваючий потенціал, який відповідає дидактичній, виховній меті заняття, а також ергономічним вимогам.

Процес вибору готового мультимедійного продукту для вирішення освітніх завдань надзвичайно складний, оскільки лише деякі готові 
продукти можуть відповідати тематиці дисциплін i тим високим вимогам щодо достовірності, репрезентативності та повноти матеріалу. Це пов'язано з тим, що у створенні продуктів не завжди беруть участь фахівці-предметники, які володіють необхідними знаннями у спеціальній галузі. А ті автори, котрі намагаються працювати спільно 3 технічним персоналом над створенням подібних мультимедіа-додатків, погано знають специфіку цього комп'ютерного жанру і психологію сприйняття інформації, представленої на екрані комп’ютера.

Тому сьогодні $\epsilon$ актуальною проблема оволодіння майбутніми викладачами вокалу технологією створення мультимедійних навчальних продуктів відповідно до мети та завдань навчальних курсів і дисциплін.

Ми вважаємо, що 3 позиції компетентнісного підходу сьогодні компетентність викладача вокалу в галузі мультимедіа становить не лише оволодіння ними як засобом навчання у процесі фахової підготовки, але і є одну зі сторін його фахової зрілості. Звідси, на нашу думку, випливає доцільність включення до фахового компетентнісного ряду майбутнього викладача вокалу ще однієї складової частини компетентності з мультимедійних і комп'ютерних технологій.

Компетентність завжди виявляється в діяльності. Не можна виявити непроявлену компетентність. Сьогодні поняття інформаційної компетентності не є загальноприйнятим та однозначно визначеним. Вчені-інформатики це поняття розглядають як сукупність знань і вмінь, що визначають результативність праці, обсяг навичок виконання завдання, комбінацію особистісних якостей і властивостей, комплекс знань і професійно значущих якостей, вектор професіоналізації, єдність теоретичної та практичної готовності до праці, здатність здійснювати складні культуровідповідні види дій тощо.

Проведений аналіз наукових джерел засвідчує, що сьогодні робляться спроби класифікувати увесь масив музичного програмного забезпечення за ознаками: 1) функціональною; 2) вирішення композиторських і виконавських проблем; 3) функціонування евристичних процесів.

Враховуючи наукові розробки та беручи за основу класифікацію технологій за функціональними можливостями, окреслимо найбільш поширені та затребувані, на наш погляд, у музичному навчанні та фаховій підготовці студентів музичні програмні засоби: 1) нотні редактори (Finale, Sibelius і подібні); 2) звукові редактори (Sony Sound Forge, Adobe Audition, Audacity); 3) кластер автоаранжувальників (Band-in-a-Box, Jammer Pro); 4) музичні конструктори (Sony Acid Pro); 5) секвенсери (FL Studio, Steinberg Cubase); 6) модулі, що розширюють додаткові можливості обробки звуку; 7) програми для роботи з вокалом 
(Celemony Melodyne); 8) програми для створення (відтворення) караоке (караоке-редактори, караоке-плеєри, відео-редактори); 9) навчальні музичні комп'ютерні програми (музично-теоретичні та музичноісторичні курси, вокальна підготовка, програмні засоби для розвитку та вдосконалення музичних здібностей, гри на музичних інструментах, мультимедійні посібники із фахових методик).

Розглянемо методичні аспекти використання окремих програмних засобів (можливості використання як допоміжного засобу у вивченні фахових дисциплін, а також інструменту фахової діяльності).

1) Звукові редактори.

Методичні аспекти їх використання:

запис, редагування й обробка звукової інформації, відбір i конструювання аудіоматеріалу для створення мультимедійних продуктів, аудіоальбомів, аудіохрестоматій, обробка готових фонограм. Можливість подальшого використання як дидактичного матеріалу на занятті завдяки візуалізації звуку, а також як одна із форм контролю й оцінювання знань (музичні вікторини, тести, звукові файли для проведення цифрових диктантів).

2) Нотні редактори.

Методичні аспекти їх використання:

набуття навичок комп'ютерного набору нотного тексту; візуалізація музичного твору, програвання партитури й озвучення іiї різноманітними тембрами; створення дидактичного нотного матеріалу, тестових завдань і їх технічне тиражування; створення репертуарних збірників, нотних посібників, озвучення партитур різноманітними тембрами віртуального хору або оркестру, що дозволить використовувати програму як тренажер для відпрацювання вокально-виконавських прийомів, ансамблевого співу.

3) Програми аудіо-конструктори.

Методичні аспекти їх використання:

створення власних музичних композицій із готових звукових зразків, комбінуючи їх відповідно до власного творчого задуму та синхронізуючи у темпі, розмірі, тональності.

4) Програми автоаранжувальники (автокомпозитори).

Методичні аспекти їх використання:

створення оркестрових супроводів для пісень, шляхом гармонізації мелодії, стилістичні варіанти оформлення, широка тембральна палітра, «яка $\epsilon$ визначальною в сучасному сприйнятті музичного твору»?,

${ }^{7}$ Бондаренко А.В. Формування пізнавальної самостійності майбутніх учителів музики з використанням мультимедійних технологій : автореф. дис. ... канд. пед. наук : 13.00.02. Київ, 2013. 20 с. 
що уможливлюе «випробувати звучання музичної побудови у виконанні різних типів оркестрів і сольних інструментів» ${ }^{8}$.

5) Програми для створення та співу караоке.

Методичні аспекти їх використання:

засіб активізації пізнавального інтересу на заняттях із вокалу, можливість транспонування та зміни темпу музичного твору, для створення комфортних умов співу.

6) Програми секвенсори.

Методичні аспекти їх використання:

можливість аранжування композицій, майстеринг. Вивчення акустичних феноменів інструментальних i штучних джерел звуку, місць прослуховування (симуляція віртуального простору), слухацького сприйняття (психоакустика), звуковий синтез ${ }^{9}$, візуалізація музики: інформація репрезентована у вигляді доріжок, які за необхідністю довільно заповнюються звуковими фрагментами «регіонами». Так, наприклад, як «регіон» можна використовувати як звуковий файл, так і будь-яку його частину. Кожній доріжці відповідає графічне зображення амплітудної обвідної, що відображає зміни гучності звучання «регіонів», та інші недеструктивні перетворення ${ }^{10}$.

7) Програми для відтворення звуку та запису на електронні носіі.

Методичні аспекти їх використання:

Можливість управління прослуховуванням, конвертація форматів звукових файлів, запис аудіо компакт-дисків. Слід зазначити, технологія візуалізації вокальної музики застосовується достатньо широко і в музичних плеєрах. Графічна основа у них модулюються графіками звукових коливань (осциллограмою або спектрограмою). Тобто програмний алгоритм генерує зображення на екрані комп'ютера, синхронізуючи їх із музикою. «Як наслідок, ми бачимо цікаві яскраві ефекти, котрі відповідають характеру i специфіці музики. А це допомагає краще зацікавити слухачів i значно підвищує результативність всього процесу слухання» ${ }^{11}$.

8 Залогова Л.А. Компьютерная графика. Элективный курс : учебное пособие. Москва : БИНОМ. Лаборатория знаний, 2005. 212 с.

9 Бондаренко А.В. Формування пізнавальної самостійності майбутніх учителів музики з використанням мультимедійних технологій : автореф. дис. ... канд. пед. наук : 13.00.02. Київ, 2013. 20 с.

${ }^{10}$ Там само.

11 Барицька О.А. Метод проектів і мультимедійні технології у у підвищені ефективності музичного навчання. Педагогіка і психологія професійної освіти. 2012. C. $48-55$. 
8) Музичні навчальні комп'ютерні програми (мультимедійні програмні засоби).

Співвідношення спеціальних музичних навчальних програм порівняно з іншими дисциплінами значно менше, що, вочевидь, можна пояснити певною специфічністю музичної освіти ${ }^{12}$.

А. Фадєєва, аналізуючи цей тип програмного забезпечення, доводить, що функціонування комп'ютерних систем, як i нейронів мозку, підпорядковане природничо-науковим законам. У постановці задач програмного забезпечення пріоритетні позиції займають складні та різноманітні моделі машинної імітації функцій людського мозку, тобто максимальне наближення до функцій інтелекту. Сучасна комп'ютерна система виконує не тільки сенсорні, але і розумові операції, як, наприклад: математичні обчислення, запам'ятовування, ретрансляцію, а також обчислювальні роботи з обробки значних масивів інформації. Така система програмного забезпечення $\epsilon$ адаптивною, наближеною до відтворення функцій мозку людини, тобто містить ознаки інтелекту ${ }^{13}$.

Науковець поділяє навчальне програмне забезпечення з погляду його структури та функцій на програми експертного (технології штучного інтелекту, здатні емалювати людське мислення) та неекспертного типу. Відмінність експертної системи від прикладних програм полягає в наявності таких ознак:

- система, крім обчислювальних операцій, формує міркування та висновки, які базуються на введених у систему знаннях;

- при розв'язанні задач основними $\epsilon$ евристичні та наближені методи.

П. Живайкін у своїй енциклопедичній роботі «600 звукових i музичних програм» класифікує навчальні музичні комп'ютерні програми відповідно до основних завдань музичної освіти:

- теоретичний матеріал (засвоєння певних закономірностей, правил побудови та фіксації музичного твору);

- спеціальні навички (досягнення певного виконавського рівня, мається на увазі початковий етап оволодіння музичним інструментом);

- розвиток слуху (здатність аналізувати музичний матеріал на слух, визначати його компоненти, тобто мелодію, інтервали, акорди, гармонічні послідовності);

- музична література (передбачає знання історії музики, біографічних відомостей про композиторів тощо) $)^{14}$.

${ }^{12}$ Бондаренко А.В. Формування пізнавальної самостійності майбутніх учителів музики з використанням мультимедійних технологій : автореф. дис. ... канд. пед. наук : 13.00.02. Київ, 2013. 20 с.

${ }_{13}$ Там само.

14 Маруфенко О.В. Формування вокально-слухових навичок майбутнього вчителя музики : автореф. дис. ... канд. пед. наук : 13.00.02. Київ, 2006. 20 с. 
Враховуючи їхню цінність і потенціал для музичного навчання у процесі фахової підготовки, проаналізуємо деякі програми на основі досліджень П. Живайкіна та А. Фадєєвої. Окремо зазначимо, що цей вид програмного забезпечення є мультимедійним.

Отже, розглянувши окремі програмні засоби для роботи 3 аудіальним матеріалом, ми визначили напрями їх застосування у трьох аспектах: як предмет вивчення, як інструмент пізнання дійсності та фахової підготовки; як засіб фахової діяльності.

Розглянемо деякі музичні програмні продукти, які, на нашу думку, доцільно використовувати у процесі вокального навчання.

1. «Claire» фірми Opcode призначена для розвитку й удосконалення вокальних даних. Програма містить більш ніж 500 вправ (мажорні, мінорні гами, інтервали, арпеджіо). Ступінь складності навчальних завдань змінюється відповідно до зростання виконавського рівня. Програмні алгоритми «здійснюють контроль» i надають усні зауваження, вказівки, відслідковується інтонаційна точність кожної виконаної ноти. Крім того, програма включає функціональну можливість ілюстрації кожної вправи для порівняльного аналізу, а також унаочнення виконаного фрагменту (вправи) у вигляді діаграми. Графіки фіксують недоопрацьовані звуки.

2. “Singing Tutor v.4.0” програма призначена для занять із вокалу та може бути використана для настроювання інструментів. Функції програми дозволяють вимірювати частоту основного тону голосу або музичних інструментів із надзвичайно високою точністю, в реальному часі, за допомогою мікрофонного входу звукової карти.

Кожному голосу відповідає певний теситурний діапазон, що візуалізується на екрані в нотному вигляді 3 виділенням верхнього регістру (6 нот). Програма автоматично встановлює можливу градацію відхилення звучання певної ноти, у кожному діапазоні існує допустима границя відхилення (на екрані це верхня та нижня горизонтальні лінії), іiі можна добирати індивідуально (від 1/4 до 1/40 тону), середня рухлива лінія відображає звучання голосу за допомогою мікрофону та дозволяє візуально здійснювати контроль за інтонуванням, сприяє слуховому розвитку. Ця програма проста та зручна в користуванні, може бути умовно віднесена до першої групи програм, у яких здійснюється зворотній зв'язок.

Як зазначалося вище, мультимедіа - синтез трьох стихій: музики, графіки, тексту. Концепція мультимедіа полягає у синергетичному впливі на різні органи сприйняття інформації. Саме тому програмні засоби для створення мультимедійних продуктів охоплюють і графічні редактори, оскільки візуалізація $є$ невід'ємною складовою частиною мультимедіа. 3 цієї позиції ми вважаємо доцільним оволодіння 
майбутніми фахівцями основами роботи у графічних комп'ютерних програмах для обробки статичної та рухомої графіки, відеопотоку, програмах презентаційної та анімаційної графіки. Функціональні можливості перерахованих програмних засобів надають можливості для створення дидактичних матеріалів і їх технічного тиражування.

Вивчаючи значення візуальних можливостей мультимедіа для майбутньої фахової діяльності викладачів вокалу, ми переконуємося у важливості оволодіння студентами основ роботи із графічними зображеннями з метою забезпечення музичної творчості. Важливим у цьому питанні буде визначення оптимального обсягу знань.

Інтеграція анімованих фрагментів у дизайні мультимедійних презентацій значно підвищує зацікавленість користувача у перегляді та засвоєнні інформації. Анімовані переходи дозволяють створювати різні рівні деталізації контенту, зберігаючи оригінальну подачу інформації. Крім того, динаміка інтерактивних елементів може розширити просторову структуру мультимедійного додатку, перенаправляючи лінійну інформацію в розгалужену.

Ми погоджуємося з таким твердженням і вважаємо, що при роботі 3 мультимедіа, їх застосуванні у згаданих напрямах фахової підготовки (предмет вивчення, засіб набуття фахових знань, інструмент фахової діяльності) необхідне стратегічне планування та прагматичний підхід до вибору мультимедійних засобів, організації навчальних занять.

Підсумовуючи викладене, зазначимо, що розглянуті нами можливості мультимедійних і комп'ютерних технологій у галузі музичного мистецтва $є$ незаперечними, прогресивними, спрямованими підняти освітню мистецьку галузь на новий якісний рівень підготовки сучасних фахівців.

Правильне поєднання усталених, перевірених часом і багаторічною практикою методів, форм організації мистецького навчання необхідно оптимально наповнювати сучасними інноваційними методиками, що передбачають ефективне використання мультимедійних технологій у процесі фахової підготовки майбутніх викладачів вокалу.

Теоретичний аналіз наукової літератури призвів до розуміння нами поняття технологій мультимедіа як комплексного утворення, яке охоплює: мультимедіа-ідею, мультиедіа-засоби, мультимедіа-продукт.

Ми вважаємо, що використання мультимедійних технологій у системі фахової підготовки майбутніх викладачів вокалу має «потрійне входження», технології мультимедіа одночасно $\epsilon$ : 1) предметом вивчення; 2) інструментом для пізнання навколишньої дійсності та здобуття фахових знань; а також 3) ефективним засобом фахової діяльності. 


\section{2. Методика формування фахової компетентності майбутнього викладача вокалу засобами мультимедійних технологій}

Форми організації освітнього процесу нерозривно пов'язані 3 методами навчання, під якими в сучасній педагогіці розуміють упорядковані способи взаємопов'язаної діяльності викладачів i студентів, скеровані на виконання навчально-виховних завдань вищої школи ${ }^{15}$.

Ми використовуємо напрацьований дидактичний шлях, де залежно від обраного критерію існує кілька класифікацій методів навчання. У класифікації методів, придатній для вищої школи, існує поділ на три групи: 1) методи організації та здійснення навчально-пізнавальної діяльності; 2) методи стимулювання й мотивації навчальнопізнавальної діяльності; 3) методи контролю i самоконтролю за ефективністю навчально-пізнавальної діяльності студентів.

Як зазначають учені, особливістю методів викладання у вищій школі є їх т. зв. бінарність, тобто паралельність або тотожність формам організації навчального процесу. Так, лекція $\epsilon$ водночас формою i методом викладання. Але всередині кожної форми, об'єднаної методично воєдино з методом, розташовується багато прийомів одноразових дій викладача ${ }^{16}$.

Аналіз праць провідних українських і зарубіжних педагогів у світлі проблеми формування фахової компетентності переконує, що з метою досягнення бажаного результату необхідно використовувати комбінацію форм і методів, а перевагу слід віддавати тим, які дають можливість гарантованого досягнення результату. Обираючи методи навчання, ми також брали до уваги положення про те, що викладання у ВН3 є системою організації й управління пізнавальною діяльністю студентів у процесі вивчення ними відповідних предметів. У цьому вивченні переважає самостійне набуття знань. Отже, як зазначає С. Архангельський, у методах навчальної роботи вищої школи основним $є$ не повідомлення студентам змісту предмета, а розвиток у них здатності та навичок самостійного набуття знань i вмінь та їх використання для розв'язання навчальних, наукових i професійних завдань ${ }^{17}$. Критерієм їх добору, на нашу думку, $є$ відповідність визначеним принципам.

15 Алексюк А.М. Педагогіка вищої освіти України: теорія : підручник. Київ : Либідь, 1998. 560 с.

16 Зимняя И.А. Ключевые компетенции - новая парадигма результата образования. Высшее образование сегодня. 2003. № 5. С. 34-42.

${ }^{17}$ Економічна енциклопедія : у 3 т. / редкол. : С.В. Мочерний (відп. ред.) та ін. Київ : Видавничий центр «Академія», 2000. Т. 1.956 с. 
Тому у процесі формування фахової компетентності майбутнього викладача вокалу ми віддали перевагу таким методам, об'єднуючи їх у кластери. Кластер (від англ. cluster) - скупчення декількох однорідних елементів, яке може розглядатися як самостійна одиниця, що характеризується певним властивостями. Перерахуємо визначені методи: 1) кластер інтерактивних методів (метод проектів, кейстехнологій, метод-тренінгу); 2) кластер евристичних методів (синектики, «мозкового штурму», евристичних завдань, колективного пошуку, вільних асоціацій, емпатіі), а також нами виокремлено метод 3) кореляції аудіо-, відео- та графічної інформації; та 4) алгоритмізації та оптимізації дій.

Керуючись принципом включення у навчальний процес стратегії менеджменту, ми вважали доцільним застосування кластеру інтерактивних методів: метод проектів, кейс-технологій, методтренінгу навчання, які передбачають діалогову взаємодію між суб'єктами навчання. Інтерактивна діяльність на заняттях із постановки голосу передбачає організацію і розвиток діалогового спілкування, що веде до взаєморозуміння, взаємодії, до спільного вирішення загальних, але значимих для кожного учасника завдань. Інтерактивне навчання виключає домінування як одного виступаючого, так і однієї думки над іншими. У ході діалогового навчання учні вчаться критично мислити, вирішувати складні проблеми на основі аналізу обставин і відповідної інформації, зважувати альтернативні думки, приймати продумані рішення, брати участь у дискусіях, спілкуватися з іншими людьми.

Діалог є не лише одним із методів навчання, а й невід'ємним компонентом, внутрішнім змістом технології навчання, «не лише засобом, але й самоціллю навчання, не тільки процесом, але й змістом, джерелом особистісного досвіду, фактором актуалізації смислотворної, рефлексивної, критичної та інших функцій особистості» ${ }^{18}$.

Внаслідок діалогічної діяльності вчителя стає можливою зміна позиції учня: 3 об'єкта впливу він перетворюється на суб'єкт активності, що істотно змінює сам педагогічний процес. Діалог допомагає студентам знайти власні цінності й сенси життя та діяльності ${ }^{19}$.

Роль викладача при використанні інтерактивних методів навчання за своєю суттю наближається до ролі менеджера, який керує роботою групи, що вирішує певну проблему або реалізує проект. У зв'язку з цим

18 Маруфенко О.В. Формування вокально-слухових навичок майбутнього вчителя музики : автореф. дис. ... канд. пед. наук : 13.00.02. Київ, 2006. 20 с.

${ }^{19}$ Економічна енциклопедія : у 3 т. / редкол. : С.В. Мочерний (відп. ред.) та ін. Київ : Видавничий центр «Академія», 2000. Т. 1.956 с. 
стає актуальним набуття викладачем основних менеджерських компетенцій, що реалізуються у процесах планування, організації та контролю власної діяльності та діяльності учнів.

Кластер евристичних методів включає такі 3 них: синектики, «мозкового штурму», евристичних завдань, колективного пошуку, вільних асоціацій, емпатії.

Евристичні методи - це система принципів і правил, які задають найбільш ймовірнісні стратегії та тактики вирішальної діяльності, стимулюючи інтуїтивне мислення у процесі вирішення, генерування нових ідей і на цій основі істотно підвищують ефективність вирішення певного класу творчих завдань. Розглянемо їх.

Аби розібратися в тому, що розуміти під евристичними методами, слід звернути увагу на те, що метод словесно можна представити у вигляді деякої системи правил, тобто опису того, як треба діяти і що потрібно робити у процесі вирішення завдань певного класу. 3 різноманітного набору правил діяльності у вирішенні завдань принципово можна виділити два великі класи приписів: алгоритми або алгоритмічні приписи й евристики - евристичні приписи. Якщо алгоритми жорстко детермінують наші дії та гарантують у разі їх точного виконання досягнення успіху у вирішенні відповідного типу завдань, то евристики й евристичні приписи лише задають стратегію і тактику, найбільш імовірний напрям пошуку ідеї рішення, але не гарантують успіху рішення.

Метод і термін «мозковий итурм», або «мозкова атака», запропоновані американським вченим А. Осборном. Евристичний діалог «мозкової атаки» базується на низці психологічних i педагогічних закономірностей. Основні принципи та правила цього методу: абсолютна заборона критики запропонованих учасниками ідей, а також заохочення усіляких реплік, жартів.

Метод вільних асоціацій. У процесі зародження асоціацій встановлюються неординарні зв'язки між компонентами розв'язуваної проблеми й елементами зовнішнього світу, включаючи компоненти колишнього досвіду творчої діяльності осіб, котрі беруть участь у колективному обговоренні проблеми, творчого завдання. Внаслідок процесу зародження нових асоціативних зв'язків виникають творчі ідеї вирішення проблеми. Ефективним є використання цього методу під час створення мультимедійної реклами музичних творів. Наприклад, керівник групи на основі методу вільних асоціацій пропонує слово, яке створює асоціативний ряд у членів групи, на основі чого генеруються нові ідеї.

Метод евристичних завдань доцільно застосовувати для збору додаткової інформації в умовах проблемної ситуації чи упорядкування 
вже наявної інформації у самому процесі вирішення творчого завдання. Евристичні питання служать додатковим стимулом, формують нові стратегії та тактики досягнення результату.

Метод інверсії спрямований на пошук ідей розв'язання творчого завдання в нових, несподіваних напрямках, найчастіше протилежних традиційним поглядам і переконанням, які диктуються формальною логікою і здоровим глуздом.

Метод інверсії базується на закономірності та принципі дуалізму, діалектичної єдності й оптимального використання протилежних (прямих і зворотних) процедур творчого мислення: аналіз і синтез, логічне й інтуїтивне, статичні і динамічні характеристики об'єкта дослідження, зовнішні і внутрішні сторони об'єкта. Якщо не вдається вирішити завдання 3 початку до кінця, то спробуйте вирішити іiі від кінця до початку.

Метод емпатії (метод особистої аналогії). Емпатія як особиста аналогія у вирішенні навчальних завдань розуміється як ототожнення людини з технічним об'єктом, процесом. Коли застосовується метод емпатії, об'єкту приписують почуття, емоції самої людини: людина ідентифікує цілі, функції, можливості, плюси і мінуси, наприклад машини, зі своїми власними. Людина як би зливається з об'єктом.

Кластер інформаційно-технологічних методів включає такі з них: авторської інтроспекції, алгоритмізації та оптимізації дій, метод кореляції відео-, аудіо- та графічної інформації.

Метод авторської інтроспекиії, запозичений нами із психології та адаптований для педагогічного процесу.

Інтроспекція (від латин. introspecto - дивлюся всередину) - метод поглибленого психологічного дослідження i пізнання людиною моментів власної активності, самоспостереження: окремих думок, образів, почуттів, переживань, актів мислення тощо.

Сутність цього методу полягає у поясненні вчителем власних творчих дій у присутності учнів (студентів).

Метод синхронізації аудіально-візуальної інформації. Під час виготовлення мультимедійних програмних продуктів: презентаційної графіки, дидактичних відеофільмів, мультимедійних рекламних роликів вокальних творів мистецтва, караоке та ін., виникає потреба у вмінні створювати та редагувати різнотипну інформацію (графіку, відео, аудіо, текст, анімацію), комбінувати та синхронізувати пї між собою, дотримуючись певних правил узгодження, конвертації та сумісності цифрових форматів. Б. Голешевич наводить цікаві прийоми використання означеного методу у шкільній практиці. «Метод синхронізації аудіо-, відеоінформації та нотації, що озвучується, призначено для використання у вокально-ансамблевій роботі, яка 
супроводжується засвоєнням нотної грамоти. На практиці це здійснюється за допомогою комп'ютера у синхронному маніпулюванні зоровими та слуховими рецепторами учнів. Переміщаючи ноти по вертикалі, обертаючи інтервали й акорди на нотоносці, відображеному, наприклад, у програмі Finale на екрані, цей вид музичної творчості стає для них привабливішим і доступнішим» ${ }^{20}$.

Метод алгоритмізації та оптимізації дій. Для успішного здійснення навчальних завдань користувачі (студенти) повинні мислити мовою інтерфейсу, тобто вміти алгоритмізувати своє мислення, оскільки алгоритм інтерфейсу підпорядкований функціональним завданням програми. Створюючи мультимедійні продукти (аранжування й обробку музичного дидактичного матеріалу), виготовляючи й опрацьовуючи статичну та відеоінформацію, студенти вчаться оптимізувати свою діяльність, обираючи найзручніші та найефективніші засоби: програмне забезпечення для створення мультимедіа (музичні, графічні, відеоредактори), оптимальніший підбір мультимедійних засобів для демонстрації навчальних завдань, здійснюючи налаштування мультимедійних компонентів. Їх мислення на цьому етапі відбувається в узгодженості з логікою функціонування програмних засобів і мультимедійних пристроїв.

Отже, процес формування компетентних викладачів вокалу в контексті інформаційного простору потребує переосмислення усталених поглядів і впровадження новітніх педагогічних технологій, методик, переоцінки основоположних принципів, наукових підходів, окреслення необхідних умов і т. ін., спрямованих на підготовку фахівців, затребуваних сьогоденним суспільством.

\section{ВИСНОВКИ}

У процесі аналізу наукової літератури були розкриті теоретикометодологічні основи процесу формування фахової компетентності викладача вокалу у контексті оволодіння мультимедійних технологій. Визначено сутність поняття «фахова компетентність майбутнього викладача вокалу», під якою ми розуміємо єдність теоретичної та практичної готовності до професійної діяльності, що $\epsilon$ структурованим набором змістових складників фахівця, який грунтується на професійному світогляді та вимірюється певними критеріями та стандартами.

Виходячи зі специфіки фахової діяльності сучасного викладача вокалу, ми пропонуємо розглядати фахову компетентність як єдність

\footnotetext{
${ }^{20}$ Иванова А. Психологическая комфортность диалога человека с комп'ютером : автореф. дис. ... канд. псих. наук : 19.00.03. Москва, 1991. С. 18. 
3 складників: мистецько-інформатичної, фасилітативної, музичнофахової.

Розкрито значення і місце мультимедійних технологій у системі фахової підготовки майбутнього викладача вокалу. На нашу думку, використання мультимедійних технологій у системі фахової підготовки майбутніх викладачів вокалу сприяє покращенню якості навчання, його оптимізації, «осучасненню» його змісту. Сучасний викладач має вміти використовувати мультимедійні технології на заняттях (уроках) i сприяти заохоченню студентів (учнів) до їх використання у власній практичній діяльності. Застосування мультимедійних технологій у процесі вивчення вокальновиконавських дисциплін сприятиме формуванню пізнавальної самостійності майбутніх викладачів вокалу.

Запропонована нами методика формування фахової компетентності майбутніх викладачів вокалу, на наше переконання, $€$ шляхом максимально ефективної інтеграції мультимедійних технологій у процес фахової підготовки викладачів вокалу й однією із запорук успішної професійної діяльності в умовах суцільної інформатизації.

\section{АНОТАЦІЯ}

У статті досліджується питання формування фахової компетентності майбутнього викладача вокалу засобами мультимедійних технологій. Проаналізовано стан вивченості «мультимедіа» у музичній галузі та визначено основні напрями його застосування. Розкрито значення і місце мультимедійних технологій у системі фахової підготовки майбутнього викладача вокалу. Обгрунтовано теоретико-методологічні основи процесу формування фахової компетентності викладача вокалу у контексті оволодіння ним мультимедійних технологій. Запропоновано методику формування фахової компетентності майбутнього викладача вокалу засобами мультимедійних технологій. У№ роботі висвітлено спеціальні функціональні методи, згруповані у кластери: інтерактивні, інформаційно-технологічні, інтерактивні. Надано найбільш ефективні методи: авторської інтроспекції, алгоритмізації й оптимізації дій, метод проектів, колективного пошуку, кореляції аудіально-візуальної інформації тощо.

\section{ЛITЕРАТУРА}

1. Алексюк А.М. Педагогіка вищої освіти України: теорія : підручник. Київ : Либідь, 1998. 560 с.

2. Баловсяк Н. Інформаційна компетентність фахівця. Педагогіка $i$ психологія професійної освіти. 2004. № 5. С. 21-28. 
3. Барицька О.А. Метод проектів і мультимедійні технології у у підвищені ефективності музичного навчання. Педагогіка $i$ психологія професійної освіти. 2012. С. 48-55.

4. Барицька О.А. Фахове удосконалення вчителів музики та образотворчого мистецтва в умовах комп'ютерного навчання. Четверті педагогічні читання пам'яті М.П. Дарманського : професіоналізм педагога в контексті європейського вибору України : матеріали всеукр. наук.-практ. конф., Хмельницький, 2 квіт. 2009 р., Хмельницька обласна рада, Хмельницька гуманітарно-педагогічна академія. Хмельницький : ХГПА, 2009. С. 37-39.

5. Бондаренко А.В. Формування пізнавальної самостійності майбутніх учителів музики 3 використанням мультимедійних технологій : автореф. дис. ... канд. пед. наук : 13.00.02. Київ, 2013. 20 с.

6. Вербицкий А.А. Активное обучение в высшей школе: Контекстный подход. Москва : Высшая школа, 1991. 105 с.

7. Горляков П.Ю. Понятие компетентности и особенности профессионально-ориентированного обучения иностранному языку. Общество. URL: http://www.terrahumana.ru /arhiv/10_03/10_03_24.pdf.

8. Економічна енциклопедія : у 3 т. / редкол. : С.В. Мочерний (відп. ред.) та ін. Київ : Видавничий центр «Академія», 2000. Т. 1.956 с.

9. Жалдак М. Використання комп'ютера в навчальному процесі має бути педагогічно виваженим. Інформатика та інформаиійні технології в навчальних закладах. 2013. № 1. С. 10-18.

10. Залогова Л.А. Компьютерная графика. Элективный курс : учебное пособие. Москва : БИНОМ. Лаборатория знаний, 2005. 212 с.

11. Зимняя И.А. Ключевые компетенции - новая парадигма результата образования. Высшее образование сегодня. 2003. № 5. C. 34-42.

12. Иванова А. Психологическая комфортность диалога человека с комп'ютером : автореф. дис. ... канд. псих. наук : 19.00.03. Москва, 1991. C. 18.

13. Іванова С.М. Структурний аналіз комунікативної компетентності майбутнього вчителя музики. Наука і сучасність. 2007. Т. 60. C. 56-64.

14. Коряпина В.В. Педагогический менеджмент как средство оптимизации образовательного процесса в учреждениях среднего профессионального образования. URL: http://dissland.com/.

15. Лепкий М. Психолог-педагогічне використання комп'ютерних тренажерів як інформаційних технологій навчання. Міжвузівський збірник «Комп'ютерно-інтегровані технологї: освіта, наука, виробниитво». 2011. № 5. С. 155-157. 
16. Маруфенко О.В. Формування вокально-слухових навичок майбутнього вчителя музики : автореф. дис. ... канд. пед. наук : 13.00.02. Київ, 2006. 20 с.

\section{Information about the authors: \\ Merezhko Yu. V.,}

Ph.D. in Pedagogical Sciences, Head of the Department of Academic and Solo Vocal Institute Chairs of Borys Grinchenko Kyiv University 18/2, Boulevard-Kudryavska str., Kyiv, Ukraine

Kychenko T. O., Lecturer at the Department of Academic and Solo Vocal Institute Chairs of Borys Grinchenko Kyiv University 18/2, Boulevard-Kudryavska str., Kyiv, Ukraine 